\title{
FGF23 and Phosphate Wasting Disorders
}

\author{
Xianglan Huang, Yan Jiang, Weibo Xia* \\ Department of Endocrinology, Key Laboratory of Endocrinology, Ministry of Health, Peking Union Medical College Hospital, \\ Chinese Academy of Medical Sciences, Shuaifuyuan No. 1, Wangfujing, Dongcheng District, Beijing 100730, China
}

A decade ago, only two hormones, parathyroid hormone and $1,25(\mathrm{OH})_{2} \mathrm{D}$, were widely recognized to directly affect phosphate homeostasis. Since the discovery of fibroblast growth factor 23 (FGF23) in 2000 (1), our understanding of the mechanisms of phosphate homeostasis and of bone mineralization has grown exponentially. FGF23 is the link between intestine, bone, and kidney together in phosphate regulation. However, we still do not know the complex mechanism of phosphate homeostasis and bone mineralization. The physiological role of FGF23 is to regulate serum phosphate. Secreted mainly by osteocytes and osteoblasts in the skeleton (2-3), it modulates kidney handling of phosphate reabsorption and calcitriol production. Genetic and acquired abnormalities in FGF23 structure and metabolism cause conditions of either hyper-FGF23 or hypo-FGF23. Hyper-FGF23 is related to hypophosphatemia, while hypo-FGF23 is related to hyperphosphatemia. Both hyper-FGF23 and hypo-FGF23 are detrimentalto humans. In this review, we will discuss the pathophysiology of FGF23 and hyper-FGF23 related renal phosphate wasting disorders (4).

Keywords: FGF23; Klotho; hypophosphatemic rickets; XLH; ADHR; ARHR; ENS; OGD; NF; McCune Albright syndrome; DMP-1; PHEX

Bone Research (2013) 2: 120-132. doi: 10.4248/BR201302002

\section{Introduction}

According to pathogenesis, ricketsis classified into calic openic rickets, phosphopenic ric kets, and a misc ellaneous group associated with direct inhibitors of mineralization (5). In general, most instances of nutritional rickets are calic openic, whereas heritable causes are usually phos phopenic. In this review we focus on hypophosphatemic rickets or osteomalacia. The causes of hypophosphatemia are various, of whichthe most prominent one is decreased reabsorption of phosphate in the proximal tubule.Although renal tubular disease can result in excessive renal phosphate wasting, in most hypophosphatemic disordersno abnomalities are found in the proximal tubule (6-7). It is speculated that an unknown factor is responsible for this phenomenon. The discovery of fibroblast growth factor 23 (FGF23), a member of the

*Correspondence: Weibo Xia

E-mail: xiaweibo@medmail.com.cn

Tel: 86-10-6915-5076, Fax: 86-10-6915-5076

Received 02 April 2013; Accepted 25 April 2013
FGF family, which mediates renal tubular defects in phosphate reabsomtion, has given new light to understandinghypophosphatemic disorders. FGF23 was identified by positional cloning in 2000 as the gene responsible for autosomal dominant hypophosphatemic rickets (ADHR) (1). Subsequent analyses indicate that several kinds of hypophosphatemic rickets are associated with high circulatory levels of FGF23. Thus, hypophosphatemic rickets can now be divided into types that are FGF23-mediated and those that are not (4). Table 1 lists FG F23 related and unrelated hypophophatemic rickets/ osteomalacia.

\section{Phosphate homeostasis}

Phosphate comprises about $1 \%$ of total body weight. About $85 \%$ of total body phosphate resides in the bone, $14 \%$ in the cells, and only $1 \%$ in the serum and extracellular fluids. Maintenance of serum phosphate within its nomal range allows for optimal mineralization of bone without deposition in vascular and other soft tissues. Serum phosphate concentration is determined 
by the balance among intestinal absorption of phosphate from the diet, itsstorage in bone, and its exc retion in the unine. The proximal tubule is responsible for the reabsorption of phosphate filtered at the glomerulus and is the primary regulator of phosphate balance in the body. Transportation in the proximal tubule is driven primarily by sodium-potassium ATPase, which is located in the baso-lateral membrane of the cell (8-11). Under nomal conditions, about $85 \%$ of the filtered phosphate is reabsorbed via the sodium-phosphate co-transporter (NaPi2a and $\mathrm{NaPi2c}$ ) in the proximal tubule $(9,11)$. Parathyroid hormone (PTH) is one of the most potent homonal regulators of phosphate transport and promotes renal exc retion of phosphate. It has now become clear that the mechanism of action of PTH is to stimulate endocytosis of the NaPi2a co-transporters from the apical membrane of the proximal tubule cells $(9,12)$. FGF23 is also an important factor resulting in renal phosphate wasting. FGF23 acts in conjunction with PTH to decrease phosphate reabsorption by down-regulating NaPi2a and $\mathrm{NaPi2c}$ expression in the brush border of the proximal tubule (13-16). This, in tum, results in hyperphosphaturia and hypophosphatemia. FGF23 is a counter-regulatory hormone for $1,25(\mathrm{OH})_{2} \mathrm{D}$ in the bonekidney feedback loop. 1,25(OH) 2 D stimulates FG F23 production, resulting in increased circulating FGF23, which in tum suppresses $1,25(\mathrm{OH})_{2} \mathrm{D}$ concentrations. The mechanism will be discussed later. Thus, conditions a ssociated with FGF23 excess characteristic ally have suppressed or inappropriately nomal circulating $1,25(\mathrm{OH})_{2} \mathrm{D}$ concentrations in the face of hypophosphatemia.

Table 1 Types of hypophosphatemic rickets/osteomalcia

\begin{tabular}{ll}
\hline FGF 23 & Types \\
\hline related & X linked hypophosphatemic rickets (XLH) \\
& Autosomal dominant hypophosphatemic ric kets (ADHR) \\
& Autosomal recessive hypophosphatemic rickets (ARHR) \\
& Tumor induced osteomalacia (TO) \\
& Fibrous dysplasia (FD)/McCune Albright Synd rome (MAS) \\
& Neurofibromatosis (NF) \\
& Hypophosphatemic rickets and hyperpa rathyroidism (HRHPT) \\
& Osteoglophonic dysplasia (OGD) \\
& Lnearnevus sebaceous syndrome (LNSS) \\
Hereditary hypophosphatemic ric kets with hypercalciuria (HHRH)
\end{tabular}

Long term hypophosphatemia can result in rickets in children, while it can result in osteomalacia in adults. The clinical signs of hypophosphatemic rickets include squared skull and bowing of the legs, while adults typically present with bone pain and pathologic fracture. In the growth plate, hypophosphatemia causes arrest of apoptosis in the hypertrophic chondrocytes leading to rickets, while in the osteoblasts, hypophosphatemia inhibits maturation and mineralization, leading to osteomalacia (17).

\section{FGF23 and phosphate regulation}

The disc overy of FGF23

Prader was the first to propose the idea of a circulating factor that could cause phosphate wasting (18). The first evidence that a circulating factor was responsible for the hypophosphatemia of phosphaturic disorders was demonstrated by Meyer et al and Nesbitt et al (19-20). The first to support this concept in humans were the findings from Miyauchi et al (21). This phosphaturic substance wastermed 'phosphatonin' by Econs and Drez- ner (22) because of its ability to lower blood phosphorus levels. The first identification of FGF23 as the putative phosphatonin was when mutations in FGF23 were identified as the cause of autosomal dominant hypophos phatemic rickets (ADHR) (1). Since then, FG F23 has been found to be related to numerous hypophosphatemic disorders.

\section{The structure of FGF23}

FGF23 is a glycoprotein with 251 amino acids. There is a signal peptide of 24 amino acids in the $\mathrm{N}$-terminal portion of the FG F23 protein. Next to the signal peptide is the FGF homology region, which binds to FG F receptors (FGFR) in the tissue. Its C-teminal peptide binds to its co-receptor Kotho which is also a transmembrane protein. Both the $\mathrm{N}$ and $\mathrm{C}$ terminals are participants in the homone's activity. The intact FGF23 is cleaved prior to secretion between Arg179 and Ser180 by funin recognizing Arg 176-X-X-Arg179 motif. Both C-terminal FGF23 and N-teminal FG F23 are inactive. Figure 1 is the structure and function of FGF23. Mutations near this site in the RXXR furin-like cleavage domain of FGF23 (R176Q and 

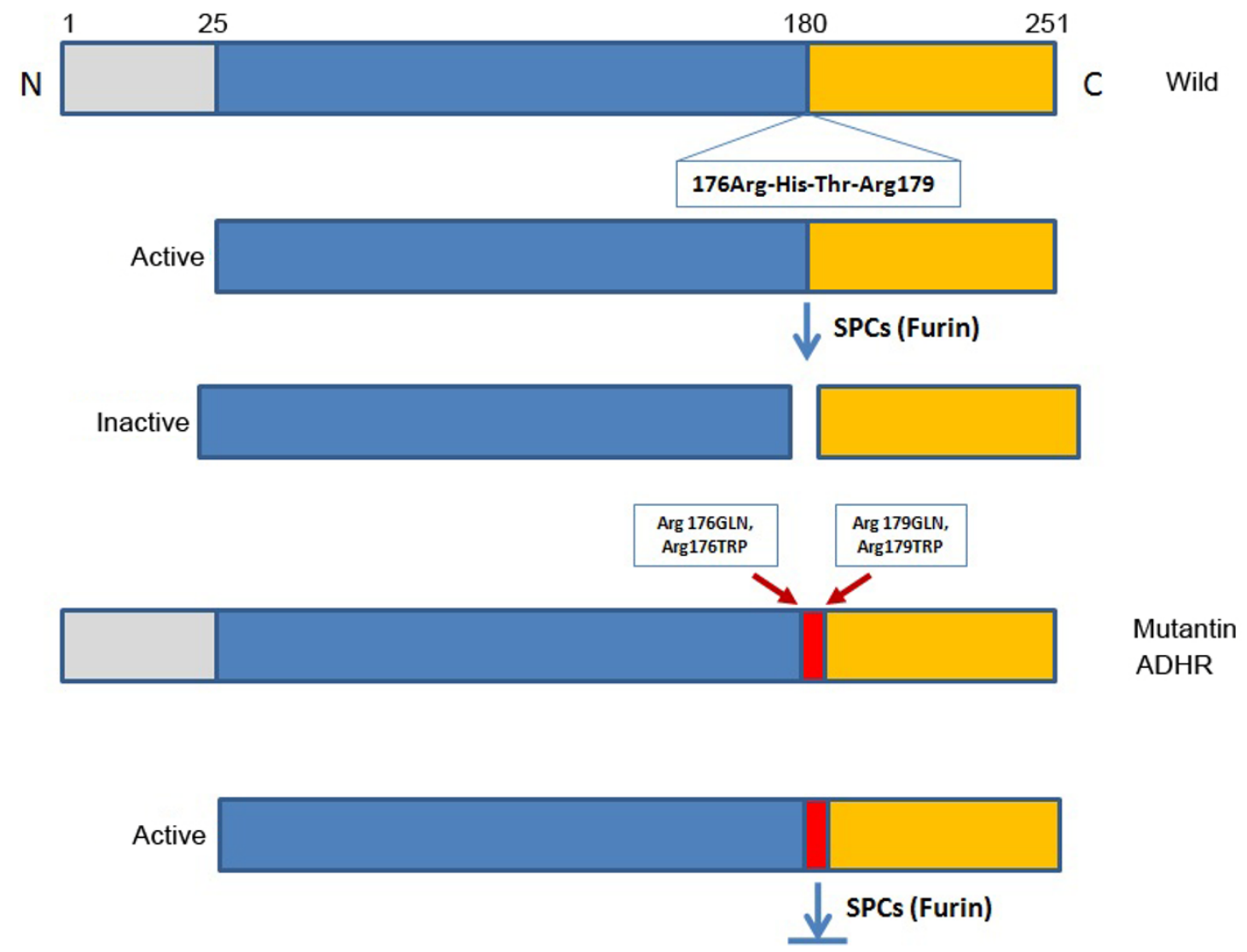

Figure 1 Schematic structure of fibroblast growth factor (FGF) 23. The FGF23 structure is schematically illustrated. FGF23 has a disulfide bond in the FGF-like sequence and internal cleavage site immediately after the R176X177X178R179 consensus sequence for convertase and cleaved into two peptides.

R179W) impair proteolytic inactivation of FGF23, resulting in high FG F23 levels and leading to autosomal dominant hypophosphatemic ric kets (ADHR) (23).

\section{Regulation of FGF23}

FGF23 is a lmost exc lusively produced by osteocytes and osteoblasts in response to high serum phosphate levels and $1,25(\mathrm{OH})_{2} \mathrm{D}(17,24)$, although aberrant production may occur in mesenchymal tumors associated with hypophosphatemic osteomalacia (25) and in the tissue of fibrous dysplasia, as in McCune-Albright syndrome with rickets (26). However, it is unclear how FGF23 secretion by bone cells is regulated. Serum phosphate and active vitamin D are positive regulators of FGF23. When serum phosphate or vitamin D levels are high, FGF23 level is elevated to increase renal phosphate wasting and to decrease active vitamin $D$ levels. In addition to being regulated by phosphate and vitamin D, some clinical evidence suggests that FGF23 production is regulated by PHEX, DMP-1, and ENPP1 genes, which encode distinct protein products, but the molecular mechanisms whereby FG F23 is regulated by these factors are unknown (27-31). PHEX, DMP-1, matrix extra cellular phosphoglycoprotein (MEPE), and acidic serine asparta te-rich MEPE associated motif (ASARM) peptides have been proposed to dynamically regulate FGF23 expression in bone (31-32). Normally, the PHEX-DMP-1 binding initiatesa signaling pathway that reduces FGF23 expression, but in XUHR and ARHR, mutations in PHEX or DMP-1, respectively, result in hypophosphatemia through increased FGF23 expression and stability which causes phosphate wasting $(25,33-35)$.

\section{FGF23 mode of action as a phosphatonin}

The physiologic effect of FGF23 is on phosphate metabolism. Although receptors to FGF23 are present in many tissues, only the kidney and parathyroid gland respond to the homone. The reason is that the phosphaturic actions of FGF23 require FGF receptors and essential cofactor Klotho to form a heterotrimer complex (36-38). Previous studies have found that the N-terminal portion of FGF23 interacts with FGFR 1c, while the C-terminal binds to Klotho and both interactions appear to be important for bioac tivity of FGF23 (29). 
Klotho, a single-pass transmembrane protein, is predominantly expressed in distal convoluted tubules in the kidney and the epithelium of the choroid plexus in the brain (39) and to a lesser extent, in the parathyroid glands (40). It servesas an obligate co-receptor, enabling FGF23 to interact with its receptor. Thus, Klotho is the modifier dic tating which tissues will respond to FGF23.

As mentioned above, FGF23 acts on the kidney to promote phosphate excretion $(13,41-43)$. The site of FG F23 action in the kidney is controversial. A "cross-talk" between the distal and proximal tubules is postulated for FGF23-induced phosphaturia based on the original notion that Klotho is exclusively expressed in the distal convoluted tubule, and phosphate reabsorption and regulation solely resides in the proximal tubule (44). There may be some proximal tubule expression, but it is clear that the majority of renal Klotho expression is in the DCT (45), While a distal-proximal cross-talk is still possible, FGF23 likely a Iso has direct action on the proximal tubule (46). Another important function of FGF23 is to regulate serum vita min D levels. The active form of vitamin $D(1,25-$ dihydroxyvita min D3) is synthesized in the kidney from its inactive precursor (25-hydroxyvitamin D3) with 1-ahydroxylase encoded by the Cyp2 7B1 gene and is inactivated with 24-hydroxylase encoded by the Cyp24 gene. FGF23 suppresses Cyp27B1 gene expression and increases Cyp24 gene expression, so that 1-a-hydroxylase (CYP27B1) ac tivity is decreased and 24-hydroxyla se (CYP24) activity is increased, leading to reduced 1,25$(\mathrm{OH})_{2} \mathrm{D}$ concentrations (47).

Elevated concentrations of FGF23 are responsible for impaired bone mineralization. Induced hypophosphatemia is largely responsible for the features of rickets and osteomalacia, since serum phosphorus concentration plays an important role in the process of growth plate mineralization. What is less clear is whether or not hypophosphatemia is solely responsible for the osteomalacia. Recent studies have found that FGF23 (and soluble Klotho) may directly impact bone in diseases with elevated
FG F23 levels (48-49).

\section{High FGF23 and disorders with abnomal phos phate metabolism}

Since its disc overy in 2000, FGF23 has been found to be related to a number of hereditable and acquired phosphate wasting disorders. Genetic disorders include Xlinked dominant hypophosphatemic rickets, autosomal recessive hypophosphatemic rickets $(35,50-51)$, a utosomal dominant hypophospha temic ric kets (1), hypophosphatemic rickets associated with McCune-Albright syndrome (52-54) and Linear sebaceous nevus syndrome (55-57). Acquired disorders include tumor induced osteomalacia. Table 2 lists a number of FG F23-mediated hypophosphatemic disorders. Table 3 lists the biochemical findings of the various forms of hypophosphatemic ric kets.

\section{$\mathrm{XLH}$}

Clinic al features

$\mathrm{XLH}$ is the most commonly inherited form of the renal phosphate wasting disorder with a prevalence of $1 / 20000$ (58). The defective gene is on the X-chromosome and female camiers are affected (i.e., an X-linked dominant disorder). C linic al manifestations vary in severity. It frequently manifests during late infancy when the child begins walking. The patient develops skeletal deformities that primarily include bowing of the long bones and widening of the metaphyseal region. The latter is most common at costochondral junc tions (rachitic rosary) (59-60). These deformities are associated with diminished growth velocity, often resulting in short stature. Later in life, patients develop osteomalacia, enthesopathy (calcified ligaments and teno-osseous junctions), degenerative joint disease, and continued dental disease in particular tooth decay and dental abscesses. With medical therapy these abnomalities can be improved, but cannot be completely resolved.

Table 2 FGF23 mediated hypophosphatemic disorders

\begin{tabular}{|c|c|c|c|}
\hline Phosphate wasting disorders & OMIM number & Gene Location & Gene/Locus involved \\
\hline X-linked dominant hypophosphatemic rickets (XUH) & 307800 & Xp22.1 & PHEX \\
\hline Autosomal dominant hypophosphatemic rickets (ADHR) & 193100 & $12 p 13.32$ & FGF23 \\
\hline Autosomal recessive hypophosphatemic rickets 1 (ARHR1) & 241520 & $4 q .22 .1$ & DMP-1 \\
\hline Autosomal recessive hypophosphatemic rickets 2 (ARHR2) & 613312 & $6 q 23.2$ & ENPP1 \\
\hline Autosomal recessive hypophosphatemic rickets 3 (ARHR3) & 241520 or 259775 & $7 p 22.3$ & FAM $20 C$ \\
\hline \multicolumn{4}{|l|}{ or Nonlethal variant of Raine syndrome } \\
\hline Hypophosphatemic rickets and hyperparathyroidism (HRHPT) & 612089 & $13 q 13.1$ & Translocation with Klotho \\
\hline McCune-Albright syndrome (MAS) & 174800 & $20 q 13.32$ & GNAS \\
\hline Osteoglophonic dysplasia (OGD) & 166250 & 8p11.2-p11.1 & FG FR1 \\
\hline
\end{tabular}


Table 3 Biochemical findings of the various forms of hypophosphatemic rickets due to genetic mutation/translocation

\begin{tabular}{lllllllllll}
\hline Disorder & $\mathrm{Ca}$ & $\mathrm{P}$ & $\mathrm{ALP}$ & $\mathrm{UCa}$ & $\mathrm{UP}$ & TmP/GFR & $\mathrm{FGF23}$ & $\mathrm{PTH}$ & $25 \mathrm{OHD}$ & 1,25(OH) \\
\hline XLH & $\mathrm{N}$ & $\downarrow$ & $\uparrow$ & $\mathrm{N}$ & $\uparrow$ & $\downarrow$ & $\mathrm{N} \uparrow$ & $\mathrm{N}$ & $\mathrm{N}$ & $\mathrm{N}^{\wedge}, \downarrow$ \\
ADHR & $\mathrm{N}$ & $\downarrow$ & $\uparrow$ & $\mathrm{N}$ & $\uparrow$ & $\downarrow$ & $\mathrm{N} \uparrow$ & $\mathrm{N}$ & $\mathrm{N}$ & $\mathrm{N}^{\wedge}, \downarrow$ \\
ARHR1 & $\mathrm{N}$ & $\downarrow$ & $\uparrow$ & $\mathrm{N}$ & $\uparrow$ & $\downarrow$ & $\mathrm{N} \uparrow$ & $\mathrm{N}$ & $\mathrm{N}$ & $\mathrm{N}^{\wedge}, \downarrow$ \\
ARHR2 & $\mathrm{N}$ & $\downarrow$ & $\uparrow$ & $\mathrm{N}$ & $\uparrow$ & $\downarrow$ & $\mathrm{N} \uparrow$ & $\mathrm{N}$ & $\mathrm{N}$ & $\mathrm{N}^{\wedge}, \downarrow$ \\
HRHPT & $\mathrm{N}$ & $\downarrow$ & $\uparrow$ & $\mathrm{N}$ & $\uparrow$ & $\downarrow$ & $\mathrm{N} \uparrow$ & $\uparrow$ & $\mathrm{N}$ & $\mathrm{N}^{\wedge}, \downarrow$ \\
McCune-Albright & $\mathrm{N}$ & $\downarrow$ & $\uparrow$ & $\mathrm{N}$ & $\uparrow$ & $\downarrow$ & $\mathrm{N} \uparrow$ & $\mathrm{N}$ & $\mathrm{N}$ & $\mathrm{N}^{\wedge}, \downarrow$ \\
ENS & $\mathrm{N}$ & $\downarrow$ & $\uparrow$ & $\mathrm{N}$ & $\uparrow$ & $\downarrow$ & $\mathrm{N} \uparrow$ & $\mathrm{N}$ & $\mathrm{N}$ & $\mathrm{N}^{\wedge}, \downarrow$ \\
NF & $\mathrm{N}$ & $\downarrow$ & $\uparrow$ & $\mathrm{N}$ & $\uparrow$ & $\downarrow$ & $\mathrm{N} \uparrow$ & $\mathrm{N}$ & $\mathrm{N}$ & $\mathrm{N}^{\wedge}, \downarrow$ \\
OGD & $\mathrm{N}$ & $\downarrow$ & $\uparrow$ & $\mathrm{N}$ & $\uparrow$ & $\downarrow$ & $\mathrm{N} \uparrow$ & $\mathrm{N}$ & $\mathrm{N}$ & $\mathrm{N}^{\wedge}$, \\
\hline
\end{tabular}

$\wedge$ : decreased relative to the serum phosphate concentration; 1,25(OH) 2 D: 1,25-dihydroxyvitamin D; 25-OH-D: 25-hydroxyvitamin D; ALP: serum alkaline phosphatase; Ca: serum calcium; P: serum phosphate; PTH: parathyroid hormone; TmPO $4 / \mathrm{GFR}$ maximum rate of renal tubular reabsorption of phosphate normalized to the glomerular filtration rate; UCa: urinary calcium excretion; UP: urinary phosphate excretion; N: normal values; $\downarrow$ : decreased values; $\uparrow:$ increased values

Biochemic al find ings

Hypophosphatemia and low-nomal circulating 1,25dihydroxyvitamin $\mathrm{D}\left[1,25(\mathrm{OH})_{2} \mathrm{D}\right]$ levels are typical biochemical findings. Senum alkaline phosphatase (ALP) activity and 24-hour urine phosphate are elevated in children, while serum calcium is nomal, as is circulating 25-OHD. Tubular reabsorption of phosphate (TRP) is decreased.

\section{Genetics}

Genetic linkage analysis has revealed inactivating mutations in the phosphate regulating gene with homology to endopeptidases on the $X$ chromosome (PHEX), a gene located on Xp22 (61-62). PHEX protein is expressed in various tissues, including the kidney, but is most abundant in mature osteoblasts and odontoblasts. PHEX is a member of the M13 family of neutral endopeptidases. It is an integral membrane glycoprotein, which activates or degrades peptides. PHEX is sec reted largely by osteocytes, but also by osteoblasts, and is important for nomal matrix mineralization. Its role in the minera lization process is unclear at present. Serum intact FGF23 level is elevated in most XLH patients (63). FG F23 was initially referred to as a substrate of PHEX (64), but subsequent research found that FGF23 is not a direct substrate of PHEX (65). The mechanism by which PHEX regulates FG F23 remains unc lear. It is now thought that it might control mineralization by binding proteins such as DMP-1 and matrix extracellular phosphoglycoprotein, which are both members of the SIBLNG proteins and contain ASARM peptides, preventing their proteolysis and the release of ASARM peptides which inhibit mineralization (66).

\section{ADHR}

Clinic al features

ADHR is a rare disorder that was first described by Bianchine et al in 1971 (58). Clinical and biochemical findings of ADHR patients are similar to those of XLHR patients. But ADHR, unlike XUHR, shows variable and incomplete penetrance with variable symptomatology and biochemical findings depending on the age at presentation. Patients who manifest the disease in their childhood develop short stature, rickets, bone pain, lower extremity deformities, and dental abscess. Some of the children have spontaneous resolution of symptoms during adulthood. On the other hand, patients with ADHR who manifest the disease in adulthood have symptoms similar to patients with $\mathrm{TO}$. Adults have bone pain, weakness, osteomalacia, and fractures/ pseudofractures, but do not have short stature nor lowerextremity deformities. Interestingly, the majority of patients who develop the disease in adulthood are women, and pregnancy triggers the onset of symptoms (67). Studies in ADHR humans have suggested that iron deficiency may be a trigger for dysregulation of FGF23, thus inducing active disease (68). Therefore, the onset of the disease is the product of gene-environment interactions. Imel et al also showed that serum iron was negatively correlated to both C-terminal FGF23 and intact FGF23 in ADHR patients (67). These studies suggested that iron status may regulate FGF23 metabolic pathways, and that low iron status results in increased FGF23 mRNA.

ADHR is caused by heterozygous mutations in the gene encoding FGF23 which is on 12 p13 $(1,69)$. Mutations identified in ADHR are missense mutations, and in each case, the mutation alters an arginine residue at 
either position 176 or 179 . The mutations, which involve the proprotein convertase (furin) cleavage site, prevent the proteolytic processing of FGF23 to its inactive $\mathrm{N}$ - and C-terminal peptides. Mutant FGF23 proteins exhibit increased stability, are more active than wild-type FGF23, in vivo (70-71), and are likely present at elevated concentrations in ADHR patients (72). Thus, in ADHR patients, high circulating levels of FGF23 are due to decreased FGF23 degradation.

\section{ARHR}

Autosomal-recessive hypophosphatemic rickets (ARHR), is a rare disorder that is recently recognized $(3,35)$. Clinical and biochemic al findings of the affected individuals are similar to $A D H R$ and $X L H$. Clinical features include rickets, skeletal deformities, dental defects, and affected individuals develop sclerotic bone lesions and enthesopathies. The clinical presentation of ARHR is not found at birth. Affected individuals present signs of rickets/osteomalacia later during childhood and even in adulthood (73-74). ARHR type 1 is caused by inactivating mutations in dentin matrix protein 1 (DMP-1), a member of the small integrin-binding ligand $\mathrm{N}$-linked glycoprotein family of extracellular matrix proteins that augment mineralization (75-76). DMP-1 is widely expressed, but particularly abundant in bone, where it is synthesized by osteoblasts. It is involved in the regulation of transcription in undifferentiated osteoblasts. DMP-1 belongs to the SIB-UNG protein family, which includes osteopontin, MEPE, bone sialoprotein II, and dentin sialoprotein, and whose genes are clustered on chromosome $4 q 21$. DMP-1 undergoes phosphorylation during the early phase of an osteoblast's maturation and is subsequently exported into the extracellular matrix where it regulates the nucleation of hydroxyapatite. FGF23 levels are elevated or inappropriately nomal for the low serum phosphate levels. Loss of function of DMP-1results in increased transcription of FGF23 by osteocytes, but the mechanism is not clear (35).

Recently, Levi-Litan et al, Lorenz-Depiereux et al and Saito et al identified an inactivating mutation in the ectonucleotide pyrophosphatase/phosphodiesterase 1 (ENPP1) gene that cause ARHR type $2(50-51,77)$. The gene product ectonucleotide pyrophosphatase/phosphodiesterase 1 is a cell surface enzyme responsible for generating inorganic pyrophosphate, which inhibits minera lization (51). Typic ally, loss-of-function muta tions in ENPP1 cause generalized arterial calcific ation of infancy $(\mathrm{GACl})$. However, hypophosphatemic rickets has also been found in patients with ENPP1 mutation. It remains unclear how the loss-of-function mutation in ENPP1 causes hypophosphatemic rickets (and not $\mathrm{GACl}$ ), but it has been speculated that it might be through increased secretion of FGF23 (24). A recent study demonstrated that the FGF23 level is elevated in patients with mutations in ENPP1 (50). However, the mechanism has yet to be defined.

Another type ARHR with hypophosphatemia, hyperphosphaturia, dental anomalies, intracerebral calcifications and osteosclerosis of the long bones in the absence of rickets, wascalled nonlethal variant of Raine syndrome or ARHR type 3. Using whole exome sequencing, Rafaelsen et al identified compound heterozygous mutations in family with sequence similarity 20 , member C (FAM20C) in patients with ARHR type 3. DMP1 is phosphorylated by FAM20C, with partial loss of Fam20c function, DMP1 is not properly phosphorylated, seems to be a mechanism that is involved in the pathways that generate FGF23-dependent hypophosphatemia (78).

\section{Cument and future treatments in hypophospha- temic rickets}

Basic therapy

Renal phosphate wasting is the principal pathophysiological abnomality that leads to all these disorders. Current treatment for patients with FGF23-dependent hypophosphatemic rickets is based on the association of activa ted vita min D metabolites (calcitriol or a lfacalcidol) and oral inorganic phosphate salts. Treatment during growth partially corrects leg deformities, decreases the number of surgeries, and may improve adult height. Early initiation of treatment appears to optimize height outcomes (79-80). However, the improvement is often partial (81).

Although an impaired growth homone (GH)-insulin like growth factor-I axis is not the primary cause of short stature in XLHR patients, GH is useful to improve growth in poorly growing XLHR patients (82). However, the results are not conclusive, as some patients do not have a recovery of growth during $\mathrm{GH}$ treatment. Orthopedic surgery is indic ated when healing of skeletal deformities of the lower limbs by medic al treatment is unsatisfactory.

With the recognition of increased FGF23 levels in the pathogenesis of these renal phosphate wasting disorders, new therapeutic strategies are being developed. One study found that subcuta neous injection of salmon calcitonin in XUHR patients causes a significant and sustained drop in circulating levels of FGF23, with an increase in serum phosphate levels (83). Studies in Hyp mice have demonstrated that the inhibition of FGF23 overproduction by anti-FGF23 neutralizing antibodies can improve phosphate levels, renal tubular phosphate reabsomtion, and bone mineralization (84-85). These 
results indic ate that inhibition of FGF23 activity is a promising therapy for FGF23-dependent hypophosphatemia. However, further studies are needed to determine whether these findings in mice can be applied to humans.

Tumor-induced osteomalacia (TO)

Tumor-induced osteomalacia (TO), or oncogenic osteomalacia, is a rare paraneoplastic syndrome of abnomal phosphate and vitamin D metabolism caused by typically small endocrine tumors. Clinic al symptoms include chronic bone pain, which is usually the first presentation, weakness, and fatigue in association with a high risk of fragility fractures. Due to under-recognition of the disease, the diagnosis is commonly delayed foryears. At our hospital, patients frequently present with multiple fractures, height loss, and a generalized debilitated status. Biochemical hallmarks of the disorder a re similar to hypophosphatemic rickets. The diagnosis is confimed by the dramatic improvement of symptoms and correction of metabolic abnomalities following complete excision of the responsible tumor.

The tumors are usually very small in size and their locations are often obscure. They can arise in bone or soft tissue, in any part of the body, and they grow slowly.

Most histologic diagnoses have been classified as phosphaturic mesenchymal tumors (PMT). A characteristic histologic feature of such tumors is a background of spindle cells that tend to have low mitotic activity, prominent vascularity, osteoclast-like giant cells, or the presence of bony tissue. Although most of these tumors are thought to have a benign histologic appearance, malignant presentation and metastases can occur (8690). While metastases are rare, infiltration of sumounding connective tissue is typically present, which has significant implic ations for surgic al management and emphasizes the importance for wide surgical margins to avoid persistence or recurrence.

Numerous reports show elevation of FGF23 in some, but not all, patients with TO (91-92). Removal of the tumor is associated with reduction in serum FGF23 concentrations, and there is a temporal association between the reduction in FGF23 concentration and the elevation in senum phosphate, decrease in renal phos phate wasting, and increase in $1,25(\mathrm{OH})_{2} \mathrm{D} 3$ concentrations (93-94). The diagnosis of TIO can be challenging because the tumors are often small and diffic ult to find. Bone scanning, computerized tomography (CT) (95), magnetic resonance imaging (MRI), Indium-111 pentetreotide or octreotide scintigraphy, and positron emission tomography (PET) have all been employed in an effort to localize the tumor (96). A stepwise approach, first performing functional tests and then anatomical tests, is advocated. In our hospital, we ha ve successfully used 99Tcm-OCT scintigraphy to locate tumors in most patients with TIO as we previously reported (94). Therefore, we prefer octreotide scintigraphy as the first approach. As for patients who are octreotide negative, when a tumor is highly suspected, we use FDG-PET/CT. Recently, 68Ga-DOTANOC PET/CThas been explored as a means of finding TIO tumors (97). Once suspicious lesions have been identified with functional imaging, one should proceed to anatomical imaging such as $\mathrm{X}$-rays, CT, and/or MRI scans to confim the location of the tumor.

The treatment of choice for $\mathrm{TOO}$ is resection of the tumor with a wide marg in to ensure complete resection. Resection with a wide surgical margin is very important, as recurrences of these tumors have been reported $(89-90,98)$. Therefore, intermittent monitoring of patients after tumor resection should be perfomed. Tumor resection is almost always curative, and following complete resection of the tumor, there is relatively rapid improvement. FG F23 disa ppears ra pidly from the circulation (99) and serum phosphate retums to normal within five days post operation (94). Most patients feel better within days to weeks of tumor removal. Bone healing starts immediately, but depending on the severity of the disease, it may take a year or more for signific ant clinical improvement.

When the tumor cannot be localized or is not surgic a ly resectable, medical therapy with phosphate supplementation and calcitriol or alfacalcidiol is used. The treatment regimen that follows is essentia lly the same as that used in non-T1O hypophosphatemia. When initiating treatment, it is prudent to check weekly labs to guide titration of medications until treatment targets are reached. Future treatment will likely be guided by a better understanding of the biology of FGF23 and the nature of these tumors.

Fibrous dysplasia (FD)/ McC une Albright Syndrome McCune-Albright syndrome (MAS) is characterized by café-au-lait spots, polyostotic fibrous bone dysplasia, and multiple endocrine hyperfunctions, such as precocious puberty, hyperthyroidism, autonomous adrenal hyperplasia, and growth hormone secreting pituitary adenoma (100). Fibrous dysplasia (FD) is a focal and benign fibrous bone lesion that is caused by the activating mutation of the Gsa protein (101-102). Hypophos phatemic rickets is sometimes observed as a complication of MAS (103).

FD and MAS are caused by somatic activating mutations of the guanine nucleotide binding protein, alpha 
stimulating gene (GNAS1), the gene encoding the alpha-subunit of the stimulatory G-protein.

Renal phosphate wasting occurs in approximately $50 \%$ of patients with MAS and FD of bone. However, the cause of hypophosphatemia is unclear. Recently, Riminucci et al (26) reported the important role of FG F23 as a cause of hypophosphatemia in MAS. However, hypophosphatemia is not always associated with MAS patients (104). Hypophosphatemia appears as the age of the MAS patients increases, which is usually accompanied by advanced bone fibrous dysplasia lesions (105). It is plausible that overproduction of FGF23 is dependent on the severity of FD bone lesions, which may be associated with increased senum FGF23 levels, and which could explain the presence or absence of hypophosphatemia in MAS patients. In situ hybridization analysis of FGF23 mRNA expression identified "fibrous" cells, osteogenic cells, and cells associated with microvascular walls as spec ific cellular sources of FGF23 in FD. Production of FGF23 by FD tissue may play an important role in the renal phosphate wasting syndrome associated with FD/MAS (26).

Treatment with bisphosphonates has been shown to reduce serum FG F23 levels, which result in a reduction of renal phosphate wasting. The mechanisms underlying the reduction of FGF23 by bisphosphonates are unclear.

Neurofibromatosis (NF)

Skeletal lesions a re not unc ommon in neurofibromatosis. Most of them are considered to be dysplastic in nature. Association of osteomalacia or rickets with NF has only rarely been documented (106-107). Osteomalacia occuming in NF is quite distinct from the more common skeletal affection seen in the disease and its pathogenesis is still unknown. Osteomalacia associated with NF1 is characterized by later onset in adulthood, renal phosphate loss with hypophosphataemia, multiple and pseudofractures in typical cases. Treatment with oral phosphate and vitamin D is effective (108-109). It is hypothesized that melatonin deficiency in cases of NF might play a role in the pathogenesis of hyperphosphaturea (110). We have a few patients who are diagnosed with neurofibromatosis and osteomalacia, while FGF23 is positive in the neurofibroma bundle of a few of the patients (data not published yet).

\section{Linear nevus sebac eous synd rome (LNSS)}

Linear nevus sebaceous syndrome (LNSS)/epidermal nevus syndrome (ENS) is a sporadic condition characterized by congenital epidemal nevi associated with anomalies in other organ systems, most commonly the central nervous system and skeleton (111). Abnorma lities in the eyes, heart, or genitourinary system have also been reported (112). Hypophosphataemic rickets is ra re (113-115) in ENS; the manifestation usually presents in the first years of life $(114,116)$. It is generally accepted that it may represent a variant of tumor-induced rickets/ osteomalacia (113-114, 117-118) characterized by renal phosphate wasting and inappropriately low serum levels of $1,25(\mathrm{OH})_{2} \mathrm{D}$. The pathogenic mechanism involved in the onset of hypophosphataemic rickets in ENS is not fully clarified. It has been proposed that FGF23 is the putative phosphatonin, based on demonstration of its elevated blood levels in a patient with LNSS (56). Subsequent studies also found the same result (119-120). In typic al tumor-induced osteomalacia, symptoms tend to be resolved after removal of the tumor (117). Exc ision of epidemal lesions with ENS may improve the hypophosphataemic rickets in some patients $(47,56)$, while it has failed to heal rickets in most patients (115-116, 118). Although it is possible that large amounts of FGF23 are autonomously secreted by LNS lesions, this factor was not found to be directly excreted from the LNS lesions (119). Further study is needed to understand the exact mechanism of how FGF23 is related to hypophosphatemic rickets in LNSS.

\section{Osteoglophonic dysplasia (OGD)}

Osteoglophonic dysplasia(OGD), also known as Fairbank-Keats syndrome, is a very rare skeletal dysplasia with craniosynostosis, and multiple lucent metaphyseal defects. It is an autosomal dominant disorder characterized by short stature, although most cases are the result of de novo mutations (121). Recently, White et al identified several heterozygous missense mutations in fibroblast growth factor receptor 1 (FGFR1) (121). These mutations are in highly conserved residues comprising the extracellular (asparagine 330 to isoleucine, Asn330lle) and transmembrane domains (tyrosine 374 to cysteine, Tyr374Cys; and cysteine 381 to arginine, Cys381Arg) of FGFR1, which seems to lead to constitutive receptor activation (122-123). Hypophosphatemia, secondary to renal phosphate wasting associated with inappropriately nomal $1,25(\mathrm{OH})_{2} \mathrm{D} 3$ levels, is present in affected individuals (124-125). FGF23 levels are elevated in some OGD patients. The elevated levels of FGF23 result in renal phosphate wasting seen in this condition (121). It is thought that the skeletal lesions in OGD patients develop because the constitutive activation of the FGFR1 leads to an up-regulation of FGF23 secretion in the metaphyseal growth plate. However, the mechanism is not yet clear. 
Hypophosphatemic rickets and hyperparathyroidism (HRHPT)

Hypophosphatemic rickets and hyperparathyroidism (HRHPT) is a syndrome featuring both hypophosphatemic rickets and hyperparathyroidism due to parathyroid hyperplasia as well as other skeletal abnomalities. Brownstein et al investigated a patient with hypophosphatemic rickets and hyperparathyroidism due to parathyroid hyperplasia (126). They found no mutation in PHEX, DMP-1, and FGF23. They found a de novo translocation with a breakpoint adjacent to alpha-Klotho, which encodes abeta-glucuronidase. Plasma alphaKlotho levels, beta-glucuronidase activity, and circulating FGF23 levels were markedly elevated. Moreover, emerging evidence indic ates that alpha-Klotho is critical for FGF23 signaling. Whether the elevated FGF23 level seen in the patient is the direct result of increased alpha-Klotho (for example, if degradation of FGF23 is prevented by interaction with alpha-Klotho), or is part of a negative-feedback loop responding to hyperparathyroid ism is diffic ult to discem at present.

\section{Conclusion}

Ric kets, due to inherited or acquired causes, remains a significant problem across the globe. Considerable advances have been made in identifying genes responsible for a number of the inherited causes of hypophosphatemic rickets and to clarify the pathways of regulation of phosphate metabolism. The discovery that FGF23 overproduction is a primary cause of hypophosphatemic rickets may suggest a new approach for the treatment of these disorders

Dysregulation of FGF23 occurs in a number of acquired and inherited disorders of phosphate homeostasis. Further investigations are required to understand the regulation of FGF23 expression.

\section{Acknowledgements}

This paper was supported by the National Natural Science Foundation of China (No. 81070687 and 81170805); National Science and Technology Major Projects for "Major New Drugs Innovation and Development" (Grant No. 2008ZX09312-016). Beijing Natural Science Foundation (No. 7121012).

\section{Reference}

1 ADHR Consortium. Autosomal dominant hypophosphataemic rickets is associated with mutations in FGF23. Nat Genet. 2000;26: 345-348.
2 Shimada T, Kakitani M, Yamazaki Y, Hasegawa H, Takeuchi Y, Fujita T, Fukumoto S, Tomizuka K, Yamashita T. Targeted ablation of Fgf23 demonstrates an essential physiological role of FGF23 in phosphate and vitamin D metabolism. J Clin Invest. 2004;113: 561-568.

3 Feng JQ, Ward LM, Liu S, Lu Y, Xie Y, Yuan B, Yu X, Rauch F, Davis SI, Zhang S, Rios H, Drezner MK, Quarles LD, Bonewald LF, White KE. Loss of DMP1 causes rickets and osteomalacia and identifies a role for osteocytes in mineral metabolism. Nat Genet. 2006;38:1310-1315

4 Pettifor JM, Thandrayen K. Hypophosphatemic rickets: unraveling the role of FGF23. Calcif Tissue Int. 2012;91:297-306.

5 Imel EA, Carpenter TO. Rickets: The skeletal disorders of impaired calcium or phosphate availability. Pediatr Endocrinol. 2013;2:357-378

6 Tenenhouse HS, Beck L. Renal $\mathrm{Na}(+)$-phosphate cotransporter gene expression in X-linked Hyp and Gy mice. Kidney Int 1996;49:1027-1032.

7 Hruska KA, Rifas L, Cheng SL, Gupta A, Halstead L, Avioli L. X-linked hypophosphatemic rickets and the murine Hyp homologue. Am J Physiol. 1995;268: F357-F362.

8 Rector FC Jr. Sodium, bicarbonate, and chloride absorption by the proximal tubule. Am J Physiol. 1983;244:F461-F471.

9 Forster IC, Hernando N, Biber J, Murer H. Proximal tubular handling of phosphate: A molecular perspective. Kidney Int 2006;70:1548-1559.

10 Tenenhouse HS. Phosphate transport: molecular basis, regulation and pathophysiology. J Steroid Biochem Mol Biol. 2007;103:572 577.

11 Miyamoto K, Ito M, Tatsumi S, Kuwahata M, Segawa H. New aspect of renal phosphate reabsorption: the type IIc sodiumdependent phosphate transporter. Am J Nephrol. 2007;27:503-515.

12 Biber J, Hernando N, Traebert M, Volkl H, Murer H. Parathyroid hormone-mediated regulation of renal phosphate reabsorption. Nephrol Dial Transplant. 2000;15 Suppl 6:29-30.

13 Quarles LD. Endocrine functions of bone in mineral metabolism regulation. J Clin Invest. 2008;118:3820-3828.

14 Quarles LD. FGF23, PHEX, and MEPE regulation of phosphate homeostasis and skeletal mineralization. Am J Physiol Endocrinol Metab. 2003;285:E1-E9.

15 Liu S, Tang W, Zhou J, Stubbs JR, Luo Q, Pi M, Quarles LD. Fibroblast growth factor 23 is a counter-regulatory phosphaturic hormone for vitamin D. J Am Soc Nephrol. 2006;17:1305-1315.

16 Liu S, Gupta A, Quarles LD. Emerging role of fibroblast growth factor 23 in a bone-kidney axis regulating systemic phosphate homeostasis and extracellular matrix mineralization. Curr Opin Nephrol Hypertens. 2007;16:329-335.

17 Tiosano D, Hochberg Z. Hypophosphatemia: the common denominator of all rickets. J Bone Miner Metab. 2009;27:392-401.

18 Prader A, Illig R, Uehlinger E, Stalder G. Rickets following bone tumor. Helv Paediatr Acta. 1959;14:554-565

19 Meyer RA Jr, Meyer MH, Gray RW. Parabiosis suggests a 
humoral factor is involved in X-linked hypophosphatemia in mice. J Bone Miner Res. 1989;4: 493-500.

20 Nesbitt T, Coffman TM, Griffiths R, Drezner MK. Cross transplantation of kidneys in normal and Hyp mice. Evidence that the Hyp mouse phenotype is unrelated to an intrinsic renal defect. J Clin Invest. 1992;89:1453-1459.

21 Miyauchi A, Fukase M, Tsutsumi M, Fujita T. Hemangiopericytoma-induced osteomalacia: tumor transplantation in nude mice causes hypophosphatemia and tumor extracts inhibit renal 25-hydroxyvitamin D 1-hydroxylase activity. J Clin Endocrinol Metab. 1988;67:46-53.

22 Econs MJ, Drezner MK. Tumor-induced osteomalacia--unveiling a new hormone. N Engl J Med. 1994;330:1679-1681.

23 Bai XY, Miao D, Goltzman D, Karaplis AC. The autosomal dominant hypophosphatemic rickets $\mathrm{R} 176 \mathrm{Q}$ mutation in fibroblast growth factor 23 resists proteolytic cleavage and enhances in vivo biological potency. J Biol Chem. 2003;278:9843-9849.

24 Ubaidus S, Li M, Sultana S, de Freitas PH, Oda K, Maeda T, Takagi R, Amizuka N. FGF23 is mainly synthesized by osteocytes in the regularly distributed osteocytic lacunar canalicular system established after physiological bone remodeling. J Electron Microsc (Tokyo). 2009;58:381-392.

25 Jonsson KB, Zahradnik R, Larsson T, White KE, Sugimoto T, Imanishi Y, Yamamoto T, Hampson G, Koshiyama H, Ljunggren O, Oba K, Yang IM, Miyauchi A, Econs MJ, Lavigne J, Juppner H. Fibroblast growth factor 23 in oncogenic osteomalacia and X-linked hypophosphatemia. N Engl J Med. 2003;348:3165631663.

26 Riminucci M, Collins MT, Fedarko NS, Cherman N, Corsi A, White KE, Waguespack S, Gupta A, Hannon T, Econs MJ, Bianco P, Gehron Robey P. FGF-23 in fibrous dysplasia of bone and its relationship to renal phosphate wasting. J Clin Invest. 2003;112: 683-692.

27 Fukumoto S, Shimizu Y. Fibroblast growth factor 23 as a phosphotropic hormone and beyond. J Bone Miner Metab. 2011; 29:507-514.

28 Alon US. Clinical practice. Fibroblast growth factor (FGF)23: a new hormone. Eur J Pediatr. 2011;170:545-554.

29 Gattineni J, Baum M. Genetic disorders of phosphate regulation. Pediatr Nephrol. 2012;27:1477-1487.

30 Carpenter TO. The expanding family of hypophosphatemic syndromes. J Bone Miner Metab. 2012;30:1-9.

31 Baroncelli GI, Toschi B, Bertelloni S. Hypophosphatemic rickets. Curr Opin Endocrinol Diabetes Obes. 2012;19:460-467.

32 Penido MG, Alon US. Phosphate homeostasis and its role in bone health. Pediatr Nephrol. 2012;27:2039-2048.

33 Martin A, David V, Li H, Dai B, Feng JQ, Quarles LD. Overexpression of the DMP1 C-terminal fragment stimulates FGF23 and exacerbates the hypophosphatemic rickets phenotype in Hyp mice. Mol Endocrinol. 2012;26:1883-1895.

34 Onishi T, Umemura S, Shintani S, Ooshima T. Phex mutation causes overexpression of FGF23 in teeth. Arch Oral Biol. 2008;53:
99-104.

35 Lorenz-Depiereux B, Bastepe M, Benet-Pages A, Amyere M, Wagenstaller J, Muller-Barth U, Badenhoop K, Kaiser SM, Rittmaster RS, Shlossberg AH, Olivares JL, Loris C, Ramos FJ, Glorieux F, Vikkula M, Juppner H, Strom TM. DMP1 mutations in autosomal recessive hypophosphatemia implicate a bone matrix protein in the regulation of phosphate homeostasis. Nat Genet. 2006;38:1248-1250.

36 Kuro-o M. Klotho as a regulator of fibroblast growth factor signaling and phosphate/calcium metabolism. Curr Opin Nephrol Hypertens. 2006;15:437-441.

37 Kurosu H, Ogawa Y, Miyoshi M, Yamamoto M, Nandi A, Rosenblatt KP, Baum MG, Schiavi S, Hu MC, Moe OW, Kuro-o M Regulation of fibroblast growth factor-23 signaling by klotho. J Biol Chem. 2006;281:6120-6123.

38 Urakawa I, Yamazaki Y, Shimada T, Iijima K, Hasegawa H, Okawa K, Fujita T, Fukumoto S, Yamashita T. Klotho converts canonical FGF receptor into a specific receptor for FGF23. Nature. 2006;444:770-774.

39 Kuro-o M, Matsumura Y, Aizawa H, Kawaguchi H, Suga T, Utsugi T, Ohyama Y, Kurabayashi M, Kaname T, Kume E, Iwasaki H, Iida A, Shiraki-Iida T, Nishikawa S, Nagai R, Nabeshima YI. Mutation of the mouse klotho gene leads to a syndrome resembling ageing. Nature. 1997;390:45-51.

40 Ben-Dov IZ, Galitzer H, Lavi-Moshayoff V, Goetz R, Kuro-o M, Mohammadi M, Sirkis R, Naveh-Many T, Silver J. The parathyroid is a target organ for FGF23 in rats. J Clin Invest. 2007;117: 4003-4008.

41 Segawa H, Kawakami E, Kaneko I, Kuwahata M, Ito M, Kusano K Saito H, Fukushima N, Miyamoto K. Effect of hydrolysis-resistant FGF23-R179Q on dietary phosphate regulation of the renal type-II Na/Pi transporter. Pflugers Arch. 2003;446:585-592.

42 Segawa H, Yamanaka S, Ohno Y, Onitsuka A, Shiozawa K, Aranami F, Furutani J, Tomoe Y, Ito M, Kuwahata M, Imura A, Nabeshima Y, Miyamoto K. Correlation between hyperphosphatemia and type II Na-Pi cotransporter activity in klotho mice. Am J Physiol Renal Physiol. 2007;292:F769-F779.

43 Shimada T, Urakawa I, Yamazaki Y, Hasegawa H, Hino R, Yoneya T, Takeuchi Y, Fujita T, Fukumoto S, Yamashita T. FGF-23 transgenic mice demonstrate hypophosphatemic rickets with reduced expression of sodium phosphate cotransporter type IIa. Biochem Biophys Res Commun. 2004;314:409-414.

44 Farrow EG, Davis SI, Summers LJ, White KE. Initial FGF23 mediated signaling occurs in the distal convoluted tubule. J Am Soc Nephrol. 2009;20:955-960.

45 Hu MC, Shi M, Zhang J, Pastor J, Nakatani T, Lanske B, Razzaque MS, Rosenblatt KP, Baum MG, Kuro-o M, Moe OW. Klotho: a novel phosphaturic substance acting as an autocrine enzyme in the renal proximal tubule. FASEB J. 2010;24:3438-3450.

46 Gattineni J, Bates C, Twombley K, Dwarakanath V, Robinson ML, Goetz R, Mohammadi M, Baum M. FGF23 decreases renal $\mathrm{NaPi}-2 \mathrm{a}$ and NaPi-2c expression and induces hypophosphatemia 
in vivo predominantly via FGF receptor 1 . Am J Physiol Renal Physiol. 2009;297:F282-F291.

47 Shimada T, Hasegawa H, Yamazaki Y, Muto T, Hino R, Takeuchi Y, Fujita T, Nakahara K, Fukumoto S, Yamashita T. FGF-23 is a potent regulator of vitamin $\mathrm{D}$ metabolism and phosphate homeostasis. J Bone Miner Res. 2004;19:429-435.

48 Shalhoub V, Ward SC, Sun B, Stevens J, Renshaw L, Hawkins N, Richards WG. Fibroblast growth factor 23 (FGF23) and alphaklotho stimulate osteoblastic MC3T3.E1 cell proliferation and inhibit mineralization. Calcif Tissue Int. 2011;89:140-150.

49 Wang H, Yoshiko Y, Yamamoto R, Minamizaki T, Kozai K, Tanne K, Aubin JE, Maeda N. Overexpression of fibroblast growth factor 23 suppresses osteoblast differentiation and matrix mineralization in vitro. J Bone Miner Res. 2008;23:939-948.

50 Lorenz-Depiereux B, Schnabel D, Tiosano D, Hausler G, Strom TM. Loss-of-function ENPP1 mutations cause both generalized arterial calcification of infancy and autosomal-recessive hypophosphatemic rickets. Am J Hum Genet. 2010;86:267-272.

51 Levy-Litan V, Hershkovitz E, Avizov L, Leventhal N, Bercovich D, Chalifa-Caspi V, Manor E, Buriakovsky S, Hadad Y, Goding J, Parvari R. Autosomal-recessive hypophosphatemic rickets is associated with an inactivation mutation in the ENPP1 gene. Am J Hum Genet. 2010;86:273-278.

52 Ryan WG, Nibbe AF, Schwartz TB, Ray RD. Fibrous dysplasia of bone with vitamin D resistant rickets: a case study. Metabolism. 1968;17:988-998.

53 Dent CE, Gertner JM. Hypophosphataemic osteomalacia in fibrous dysplasia. Q J Med. 1976;45:411-420.

54 Dachille RD, Goldberg JS, Wexler ID, Shons AR. Fibrous dysplasia-induced hypocalcemia/rickets. J Oral Maxillofac Surg. 1990;48:1319-1322.

55 Zutt M, Strutz F, Happle R, Habenicht EM, Emmert S, Haenssle HA, Kretschmer L, Neumann C. Schimmelpenning-FeuersteinMims syndrome with hypophosphatemic rickets. Dermatology. 2003;207:72-76.

56 Hoffman WH, Jueppner HW, Deyoung BR, O'Dorisio M S, Given KS. Elevated fibroblast growth factor-23 in hypophosphatemic linear nevus sebaceous syndrome. Am J Med Genet A. 2005;134: 233-236.

57 Srinivas UM, Tourani KL. Epidermal nevus syndrome with hypophosphatemic renal rickets with hypercalciuria: a bone marrow diagnosis. Int J Hematol. 2008;88:125-126.

58 Bianchine JW, Stambler AA, Harrison HE. Familial hypophosphatemic rickets showing autosomal dominant inheritance. Birth Defects Orig Artic Ser. 1971;7:287-295.

59 Pettifor JM. What's new in hypophosphataemic rickets? Eur J Pediatr. 2008;167:493-499.

60 Xia W, Meng X, Jiang Y, Li M, Xing X, Pang L, Wang O, Pei Y, Yu LY, Sun Y, Hu Y, Zhou X. Three novel mutations of the PHEX gene in three Chinese families with X-linked dominant hypophosphatemic rickets. Calcif Tissue Int. 2007;81:415-420.

61 A gene (PEX) with homologies to endopeptidases is mutated in patients with X-linked hypophosphatemic rickets. The HYP Consortium. Nat Genet. 1995;11:130-136.

62 Beck L, Soumounou Y, Martel J, Krishnamurthy G, Gauthier C, Goodyer CG, Tenenhouse HS. Pex/PEX tissue distribution and evidence for a deletion in the 3 ' region of the Pex gene in X-linked hypophosphatemic mice. J Clin Invest. 1997;99:1200-1209.

63 Xia WB, Jiang Y, Li M, Xing XP, Wang O, Hu YY, Zhang HB, Liu HC, Meng XW, Zhou XY. Levels and dynamic changes of serum fibroblast growth factor 23 in hypophosphatemic rickets/ osteomalacia. Chin Med J (Engl). 2010;123:1158-1162.

64 Liu S, Zhou J, Tang W, Jiang X, Rowe DW, Quarles LD. Pathogenic role of Fgf23 in Hyp mice. Am J Physiol Endocrinol Metab. 2006;291:E38-E49.

65 Liu S, Guo R, Simpson LG, Xiao ZS, Burnham CE, Quarles LD. Regulation of fibroblastic growth factor 23 expression but not degradation by PHEX. J Biol Chem. 2003;278:37419-37426.

66 David V, Martin A, Hedge AM, Drezner MK, Rowe PS. ASARM peptides: PHEX-dependent and -independent regulation of serum phosphate. Am J Physiol Renal Physiol. 2011;300:F783F791.

67 Econs MJ, McEnery PT. Autosomal dominant hypophosphatemic rickets/osteomalacia: clinical characterization of a novel renal phosphate-wasting disorder. J Clin Endocrinol Metab. 1997;82: 674-681.

68 Imel EA, Peacock M, Gray AK, Padgett LR, Hui SL, Econs MJ. Iron modifies plasma FGF23 differently in autosomal dominant hypophosphatemic rickets and healthy humans. J Clin Endocrinol Metab. 2011;96:3541-3549.

69 Kruse K, Woelfel D, Strom TM. Loss of renal phosphate wasting in a child with autosomal dominant hypophosphatemic rickets caused by a FGF23 mutation. Horm Res. 2001;55:305-308.

70 White KE, Carn G, Lorenz-Depiereux B, Benet-Pages A, Strom TM, Econs MJ. Autosomal-dominant hypophosphatemic rickets (ADHR) mutations stabilize FGF-23. Kidney Int. 2001;60:20792086.

71 Sun $Y$, Wang O, Xia W, Jiang Y, Li M, Xing X, Hu Y, Liu H, Meng $X$, Zhou X. FGF23 analysis of a Chinese family with autosomal dominant hypophosphatemic rickets. J Bone Miner Metab. 2012; 30:78-84.

72 Imel EA, Econs MJ. Fibroblast growth factor 23: roles in health and disease. J Am Soc Nephrol. 2005;16:2565-2575.

73 Perry W, Stamp TC. Hereditary hypophosphataemic rickets with autosomal recessive inheritance and severe osteosclerosis. A report of two cases. J Bone Joint Surg Br. 1978;60-B:430-434.

74 Scriver CR, Reade T, Halal F, Costa T, Cole DE. Autosomal hypophosphataemic bone disease responds to 1,25-(OH)2D3. Arch Dis Child. 1981;56:203-207.

75 Gattineni J, Baum M. Regulation of phosphate transport by fibroblast growth factor 23 (FGF23): implications for disorders of phosphate metabolism. Pediatr Nephrol. 2010;25:591-601.

76 Farrow EG, White KE. Recent advances in renal phosphate handling. Nat Rev Nephrol. 2010;6:207-217. 
77 Saito T, Shimizu Y, Hori M, Taguchi M, Igarashi T, Fukumoto S, Fujitab T. A patient with hypophosphatemic rickets and ossification of posterior longitudinal ligament caused by a novel homozygous mutation in ENPP1 gene. Bone. 2011;49:913-916. Rafaelsen SH, Raeder H, Fagerheim AK, Knappskog P, Carpenter TO, Johansson S, Bjerknes R. Exome sequencing reveals FAM20c mutations associated with fibroblast growth factor 23-related hypophosphatemia, dental anomalies, and ectopic calcification. J Bone Miner Res. 2013;28:1378-1385.

79 Carpenter TO, Imel EA, Holm IA, Jan de Beur SM, Insogna KL. A clinician's guide to X-linked hypophosphatemia. J Bone Miner Res. 2011;26:1381-1388.

80 Quinlan C, Guegan K, Offiah A, Neill RO, Hiorns MP, Ellard S, Bockenhauer D, Hoff WV, Waters AM. Growth in PHEXassociated X-linked hypophosphatemic rickets: the importance of early treatment. Pediatr Nephrol. 2012;27:581-588.

81 Makitie O. Early Treatment Improves Growth and Biochemical and Radiographic Outcome in X-Linked Hypophosphatemic Rickets. Journal of Clinical Endocrinology \& Metabolism. 2003;88: 3591-3597.

82 Zivicnjak M, Schnabel D, Staude H, Even G, Marx M, Beetz R, Holder M, Billing H, Fischer DC, Rabl W, Schumacher M, Hiort O, Haffner D, Hypophosphatemic Rickets Study Group of the Arbeitsgemeinschaft fur Padiatrische E, Gesellschaft fur Padiatrische N. Three-year growth hormone treatment in short children with X-linked hypophosphatemic rickets: effects on linear growth and body disproportion. J Clin Endocrinol Metab. 2011;96:E2097-E2105.

83 Liu ES, Carpenter TO, Gundberg CM, Simpson CA, Insogna KL. Calcitonin administration in X-linked hypophosphatemia. N Engl J Med. 2011;364:1678-1680.

84 Aono $\mathrm{Y}$, Hasegawa H, Yamazaki $\mathrm{Y}$, Shimada T, Fujita T, Yamashita T, Fukumoto S. Anti-FGF-23 neutralizing antibodies ameliorate muscle weakness and decreased spontaneous movement of Hyp mice. J Bone Miner Res. 2011;26:803-810.

85 Shimada T, Fukumoto S. FGF23 as a novel therapeutic target. Adv Exp Med Biol. 2012;728:158-170.

86 Wyman AL, Paradinas FJ, Daly JR. Hypophosphataemic osteomalacia associated with a malignant tumour of the tibia: report of a case. J Clin Pathol. 1977;30:328-335.

87 Rico H, Fernandez-Miranda E, Sanz J, Gomez-Castresana F, Escriba A, Hernandez ER, Krsnik I. Oncogenous osteomalacia: a new case secondary to a malignant tumor. Bone. 1986;7:325-329.

88 Harvey JN, Gray C, Belchetz PE. Oncogenous osteomalacia and malignancy. Clin Endocrinol (Oxf). 1992;37:379-382.

89 Ogose A, Hotta T, Emura I, Hatano H, Inoue Y, Umezu H, Endo $\mathrm{N}$. Recurrent malignant variant of phosphaturic mesenchymal tumor with oncogenic osteomalacia. Skeletal Radiol. 2001;30: 99-103.

90 Uramoto N, Furukawa M, Yoshizaki T. Malignant phosphaturic mesenchymal tumor, mixed connective tissue variant of the tongue. Auris Nasus Larynx. 2009;36:104-105.
91 Cai Q, Hodgson SF, Kao PC, Lennon VA, Klee GG, Zinsmiester AR, Kumar R. Brief report: inhibition of renal phosphate transport by a tumor product in a patient with oncogenic osteomalacia. N Engl J Med. 1994;330:1645-1649.

92 Yamazaki Y, Okazaki R, Shibata M, Hasegawa Y, Satoh K, Tajima T, Takeuchi Y, Fujita T, Nakahara K, Yamashita T, Fukumoto S. Increased circulatory level of biologically active full-length FGF-23 in patients with hypophosphatemic rickets/osteomalacia. J Clin Endocrinol Metab. 2002;87:4957-4960.

93 Takeuchi $Y$, Suzuki H, Ogura S, Imai R, Yamazaki Y, Yamashita T, Miyamoto Y, Okazaki H, Nakamura K, Nakahara K, Fukumoto S, Fujita T. Venous sampling for fibroblast growth factor-23 confirms preoperative diagnosis of tumor-induced osteomalacia. J Clin Endocrinol Metab. 2004;89:3979-3982.

94 Jiang Y, Xia WB, Xing XP, Silva BC, Li M, Wang O, Zhang HB, Li F, Jing HL, Zhong DR, Jin J, Gao P, Zhou L, Qi F, Yu W, Bilezikian JP, Meng XW. Tumor-induced osteomalacia: an important cause of adult-onset hypophosphatemic osteomalacia in China: Report of 39 cases and review of the literature. J Bone Miner Res. 2012;27: 1967-1975.

95 White KE, Jonsson KB, Carn G, Hampson G, Spector TD, Mannstadt M, Lorenz-Depiereux B, Miyauchi A, Yang IM, Ljunggren O, Meitinger T, Strom TM, Juppner H, Econs MJ. The autosomal dominant hypophosphatemic rickets (ADHR) gene is a secreted polypeptide overexpressed by tumors that cause phosphate wasting. J Clin Endocrinol Metab. 2001;86:497-500.

96 Farrow EG, White KE. Tumor-induced osteomalacia. Expert Rev Endocrinol Metab. 2009;4:435-442.

97 Hesse E, Moessinger E, Rosenthal H, Laenger F, Brabant G, Petrich T, Gratz KF, Bastian L. Oncogenic osteomalacia: exact tumor localization by co-registration of positron emission and computed tomography. J Bone Miner Res. 2007;22:158-162.

98 Clunie GP, Fox PE, Stamp TC. Four cases of acquired hypophosphataemic ('oncogenic') osteomalacia. Problems of diagnosis, treatment and long-term management. Rheumatology (Oxford). 2000;39:1415-1421.

99 Khosravi A, Cutler CM, Kelly MH, Chang R, Royal RE, Sherry RM, Wodajo FM, Fedarko NS, Collins MT. Determination of the elimination half-life of fibroblast growth factor-23. Journal of Clinical Endocrinology \& Metabolism. 2007;92:2374-2377.

100 Spiegel AM, Shenker A, Weinstein LS. Receptor-effector coupling by $G$ proteins: implications for normal and abnormal signal transduction. Endocr Rev. 1992;13:536-565.

101 Weinstein LS, Shenker A, Gejman PV, Merino MJ, Friedman E, Spiegel AM. Activating mutations of the stimulatory $\mathrm{G}$ protein in the McCune-Albright syndrome. N Engl J Med. 1991;325:16881695

102 Schwindinger WF, Francomano CA, Levine MA. Identification of a mutation in the gene encoding the alpha subunit of the stimulatory $\mathrm{G}$ protein of adenylyl cyclase in McCune-Albright syndrome. Proc Natl Acad Sci U S A. 1992;89:5152-5156.

103 Lee PA, Van Dop C, Migeon CJ. McCune-Albright syndrome. 
Long-term follow-up. JAMA. 1986;256:2980-2984.

104 Collins MT, Chebli C, Jones J, Kushner H, Consugar M, Rinaldo P, Wientroub S, Bianco P, Robey PG. Renal phosphate wasting in fibrous dysplasia of bone is part of a generalized renal tubular dysfunction similar to that seen in tumor-induced osteomalacia. J Bone Miner Res. 2001;16:806-813.

105 Yamamoto T, Miyamoto KI, Ozono K, Taketani Y, Katai K, Miyauchi A, Shima M, Yoshikawa H, Yoh K, Takeda E, Okada S. Hypophosphatemic rickets accompanying McCune-Albright syndrome: evidence that a humoral factor causes hypophosphatemia. J Bone Miner Metab. 2001;19:287-295.

106 Chadha M, Singh AP, Singh AP. Hypophosphataemic osteomalacia in neurofibromatosis. Acta Orthop Belg. 2009;75:847-850.

107 Lambert J, Lips P. Adult hypophosphataemic osteomalacia with Fanconi syndrome presenting in a patient with neurofibromatosis. Neth J Med. 1989;35:309-316.

108 Konishi K, Nakamura M, Yamakawa H, Suzuki H, Saruta T, Hanaoka H, Davatchi F. Hypophosphatemic osteomalacia in von Recklinghausen neurofibromatosis. Am J Med Sci. 1991;301:322328.

109 Retnam VJ, Rangnekar DM, Bhandarkar SD. Neurofibromatosis with hypophosphatemic osteomalacia (Von RecklinghausenHernberg-Edgren-Swann syndrome) (a case report). J Assoc Physicians India. 1980;28:319-322.

110 Abdel-Wanis M, Kawahara N. Hypophosphatemic osteomalacia in neurofibromatosis 1: hypotheses for pathogenesis and higher incidence of spinal deformity. Med Hypotheses. 2002;59:183-185.

111 Solomon LM, Esterly NB. Epidermal and other congenital organoid nevi. Curr Probl Pediatr. 1975;6:1-56.

112 Grebe TA, Rimsza ME, Richter SF, Hansen RC, Hoyme HE. Further delineation of the epidermal nevus syndrome: two cases with new findings and literature review. Am J Med Genet. 1993;47:24-30.

113 Aschinberg LC, Solomon LM, Zeis PM, Justice P, Rosenthal IM. Vitamin D-resistant rickets associated with epidermal nevus syndrome: demonstration of a phosphaturic substance in the dermal lesions. J Pediatr. 1977;91:56-60.

114 Carey DE, Drezner MK, Hamdan JA, Mange M, Ahmad MS, Mubarak S, Nyhan WL. Hypophosphatemic rickets/osteomalacia in linear sebaceous nevus syndrome: a variant of tumor-induced osteomalacia. J Pediatr. 1986;109:994-1000.
115 Goldblum JR, Headington JT. Hypophosphatemic vitamin Dresistant rickets and multiple spindle and epithelioid nevi associated with linear nevus sebaceus syndrome. J Am Acad Dermatol. 1993;29:109-111.

116 Skovby F, Svejgaard E, Moller J. Hypophosphatemic rickets in linear sebaceous nevus sequence. J Pediatr. 1987;111:855-857.

117 Eyskens B, Proesmans W, Van Damme B, Lateur L, Bouillon R, Hoogmartens M. Tumour-induced rickets: a case report and review of the literature. Eur J Pediatr. 1995;154:462-468.

118 Oranje AP, Przyrembel H, Meradji M, Loonen MC, de Klerk JB. Solomon's epidermal nevus syndrome (type: linear nevus sebaceus) and hypophosphatemic vitamin D-resistant rickets. Arch Dermatol. 1994;130:1167-1171.

119 Narazaki R, Ihara K, Namba N, Matsuzaki H, Ozono K, Hara T. Linear nevus sebaceous syndrome with hypophosphatemic rickets with elevated FGF-23. Pediatr Nephrol. 2012;27:861-863.

120 Sethi SK, Hari P, Bagga A. Elevated FGF-23 and parathormone in linear nevus sebaceous syndrome with resistant rickets. Pediatr Nephrol. 2010;25:1577-1578.

121 White KE, Cabral JM, Davis SI, Fishburn T, Evans WE, Ichikawa S, Fields J, Yu X, Shaw NJ, McLellan NJ, McKeown C, Fitzpatrick D, $\mathrm{Yu}$ K, Ornitz DM, Econs MJ. Mutations that cause osteoglophonic dysplasia define novel roles for FGFR1 in bone elongation. Am J Hum Genet. 2005;76:361-367.

122 Farrow EG, Davis SI, Mooney SD, Beighton P, Mascarenhas L, Gutierrez YR, Pitukcheewanont P, White KE. Extended mutational analyses of FGFR1 in osteoglophonic dysplasia. Am J Med Genet A. 2006;140:537-539.

123 Roberts TS, Stephen L, Beighton P. Osteoglophonic dysplasia: dental and orthodontic implications. Orthod Craniofac Res. 2006; 9:153-156.

124 Beighton P, Cremin BJ, Kozlowski K. Osteoglophonic dwarfism. Pediatr Radiol. 1980;10:46-50.

125 Beighton P. Osteoglophonic dysplasia. J Med Genet. 1989;26:572576.

126 Brownstein CA, Adler F, Nelson-Williams C, Iijima J, Li P, Imura A, Nabeshima Y, Reyes-Mugica M, Carpenter TO, Lifton RP. A translocation causing increased alpha-klotho level results in hypophosphatemic rickets and hyperparathyroidism. Proc Natl Acad Sci U S A. 2008;105:3455-3460. 